J OURNAL OF French and Francophone Philosophy
REVUE DE L A

philosophie française et de langue française

\title{
The Audible Life of the Image
}

\section{David Wills}

Journal of French and Francophone Philosophy - Revue de la philosophie française et de langue française, Vol XVIII, No 2 (2010) pp 43-64.

\author{
Vol XVIII, No 2 (2010) \\ ISSN 1936-6280 (print) \\ ISSN 2155-1162 (online) \\ DOI 10.5195/jffp.2010.212 \\ http: / / www.jffp.org
}

\section{(cc) EY-NC-ND}

This work is licensed under a Creative Commons Attribution-Noncommercial-No Derivative Works 3.0 United States License.

\section{ULIS D-Sont}

This journal is published by the University Library System of the University of Pittsburgh as part of its D-Scribe Digital Publishing Program, and is co-sponsored by the University of Pittsburgh Press 


\title{
The Audible Life of the Image
}

\author{
David Wills
}

University at Albany

Since at least 1980 Godard's cinema has been explicitly looking for (its) music, as if for its outside. In Sauve qui peut (la vie) Paul Godard hears, and asks about it coming through the hotel room wall, and it follows him down to the lobby, but remains "off," like Marguerite Duras's voice, in spite of his questions, until the final sequence. At that moment, at the end of the section entitled "Music," the protagonist is at the same time struck by a car and struck by the entrance of the music into the diegetic present of the film, as the camera pans past an orchestra playing on the sidewalk while Paul fades off under the quizzical gaze of his daughter. ${ }^{1}$ By 2004, with Notre musique, it would seem to have taken over the whole text, for the film was announced as being about the collaboration between Godard and German record label ECM. In the context of that film it is difficult to determine both what that music is and who we are, although this discussion will try to advance a hypothesis in that regard. In fact, my main contention will be that music in Godard's films functions as something like the absent image(s), not those it has lost but rather its cinema to come, what remains to be discovered and live within it, the survival of it. Not a cinema that cannot be seen, rather the image that can perhaps only be heard; and not the romantic or psychedelic dream of a synaesthetic apotheosis either, rather the technological coincidence of sonimage that has also been the precise direction of Godard's cinematic research for more than thirty years. For the argument I will be making here is inscribed within my own investigation of what I call "technological life," the means by which, in "prosthetic" symbiosis, or "dorsal" umbrality, a form lives beyond the simplistic opposition of animate and inanimate, or against the reductive presuppositions of autokinetic ipseity. $^{2}$

In one respect, already suggested by the name of Godard's production company, but reinforced by a variety of commentators, having music seen, or having film function beyond the formal constraints of image and sound tracks, is what Godard has always aimed for. The filmmaker has himself has spoken of "the fact that musicians don't need the image whereas people who 
make images need music. I've always wanted to do a pan or tracking shot during a war scene or love scene, so that one can see the orchestra at the same time. So that the music takes over when there is no more need to see the image, so that music expresses something else. What interests me is to see music, to try to see what is heard and to hear what is seen." ${ }^{3}$ In more general terms, however, in the context of "Godard's life-long innovations in sound design,"4 one could cite, from as early as A bout de souffle, the opening of the invisible wall between on-screen actor and spectator; or the whole complex play of sound that begins when Belmondo shoots the sky. As a means of "anchoring" some of those considerations in a musical context, I shall discuss first two sequences from Week-end, where what becomes more explicit in Sauve qui peut is already heralded, then develop my thesis further vis-à-vis the relatively recent films Éloge de l'amour and Notre musique. A straightforward idea will guide me: Godard's idea of music is inextricably related to his radical conception of montage, montage as a radical concept. That concept will be, in my terms, something like the possible impossibility, or compossibility, of a technological sovereignty.

My reference to the concept, in the context of cinema, is of course a reference to Deleuze's idea of what philosophy does best: "philosophy is the art of forming, inventing, and fabricating concepts." ${ }^{5}$ And any discussion of cinema in the context of philosophy henceforth comes across Deleuze before it is able to advance at all. Among readers of Deleuze, Claire Colebrook is most explicit in relating the philosopher's cinematic analyses to the question of life, specifically a life of intensity not reducible to the animate. "Philosophy," she writes, "can only begin to think when it steps outside its own images of mind, reason and humanity. This is why Deleuze installs technology at the heart of philosophy and life. . . Only when the human encounters the inhuman will we know what the human body can do, and only when life opens itself up to violence, destruction, death and zero intensity will we be able to discern just what counts as 'a' single life . . . . it was [in Deleuze's work on cinema] that he showed how creative philosophy and the human brain might become if we confronted our relation to machines." 6

For Deleuze, cinema is about a technological thinking in images that is capable of changing the way the human brain thinks; it is about correlating and expanding the life of the mind in that sense. To quote Colebrook again: "life is perception, or a virtual power to relate and to image. . . life is imaging, a plane of relations that take the form of perceptions precisely because something 'is' only its responses. Before there are actual terms - 'mind' on the one hand, 'world' on the other - there is a potential for relation, and relations for Deleuze are best described as images." ${ }^{7}$ The logic I shall try to develop here relies to a great extent on those Deleuzian insights. As Colebrook argues them, they appear in contrast to, or as a radical extension of another, equally legitimate understanding of Deleuze as affirming life in 
the Nietzschean sense. In his reading of Gilles Deleuze's Time Machine, David Rodowick emphasizes how "the time-image lets us believe again in 'life.' This is neither a romantic nor a vague metaphysical concept. . . . life is change." ${ }^{8}$ Quoting such passages as Deleuze's invocation of the Nietzschean advocacy of "outpouring, ascending life, the kind which knows how to transform itself, to metamorphose itself according to the forces it encounters," ${ }^{9}$ Rodowick makes clear that the stakes of such an affirmation of life involve thinking "what we have not yet become . . . . acknowledg[ing] change and becoming as forces, or the force of time as change."10 An altogether different life, therefore. But that is a different emphasis from Colebrook's insistence, as Deleuze puts it, on a "powerful, non-organic Life which grips the world." 11

The 1967 film Week-end is one among many--no doubt any--of Godard's first period commercial films that raise the question of the sonic other of the image. What makes it exemplary for my purposes-apart from its being the last film he made before his Dziga-Vertov collective experiment--is the fact of its well-known on-screen musical performance, one that is accompanied by a striking play of the image. About two thirds of the way through the film the murderous husband and wife protagonists, Roland and Corinne, hitch a ride on a truck driven by an itinerant pianist. In the following sequence we are treated to an Action Musicale (as the intertitle tells us) that consists of a single (7 minutes 18 seconds) shot consisting of three, almost $360^{\circ}$ panoramic sweeps of a farm estate, to the accompaniment of Paul Gégauff playing a Mozart piano sonata. His piano has been installed in front of the barn and his audience consists of a more or less accidental assembly of curious or bored farmworkers, a couple of young lovers, and the protagonist couple. During the first two $360^{\circ}$ counterclockwise pans, each of which lasts about two minutes, Gégauff twice plays a one minute extract of the sonata, stopping at approximately the same point to offer short discourses (53 seconds, 30 seconds) on the place of Mozart in the history of music. Following that, during a clockwise pan, he continues his performance for a little over $3 \frac{1}{2}$ minutes, up to the end of the sequence.

There is therefore a coherence and unity to the sequence (a "scene" according to Metz's categories ${ }^{12}$ ), which is precisely provided by the music and the pianist's commentary (the only other dialogue consists of two quick, garbled questions or comments uttered by Corinne). That sonic coherence is reinforced by the fact that for three of its four static moments, the camera pauses on the pianist. The on-screen musical performance would therefore seem to provide the narrative signification of the sequence: what takes place is the recital. However, the visual track also offers two different, clearly identifiable cohering structures. The first is provided by a farmworker who is in the frame at the beginning of the take, and remains its focus until a point of divergence when the camera leaves him behind, just before it glimpses the couple I have referred to as young lovers are glimpsed walking 
from background to foreground. The farmworker will reenter the frame almost six minutes later--in the third, clockwise panorama--now carrying a shovel that he seems to have gone to retrieve, ostensibly returning to his work (however much he dawdles), and he will disappear up the haybarn stairs, behind the piano, at the end of the sequence. He therefore reinforces a thematic of class opposition or conflict that has already been developed in the film, incarnating a proletarian counterpoint to the leisured class (although they are also predominantly rural workers) of idle music devotees. One would have to accept, within the context of the film up to this point, but also in view of the fact that the sequence begins and ends with his movements, that his actions constitute a narrative with as valid a claim to importance as the musical performance: what takes place is the farmworker going about his work.

The contrast between laboring and leisured, or landed, classes is reinforced by the appearance of a second competing visual structure, which works around the couple of young lovers. They appear in the frame--to replace the disappearing workman--in front of the chateau, and might be imagined to have emerged from it. They inhabit the foreground for about 40 seconds towards the end of the second panorama, approaching the piano to listen to the recital. The female character is played by Anne Wiazemsky, star of La Chinoise, and Godard's new wife of a few months. She is captured sauntering alone in front of the camera for a few seconds of spectator delectation.

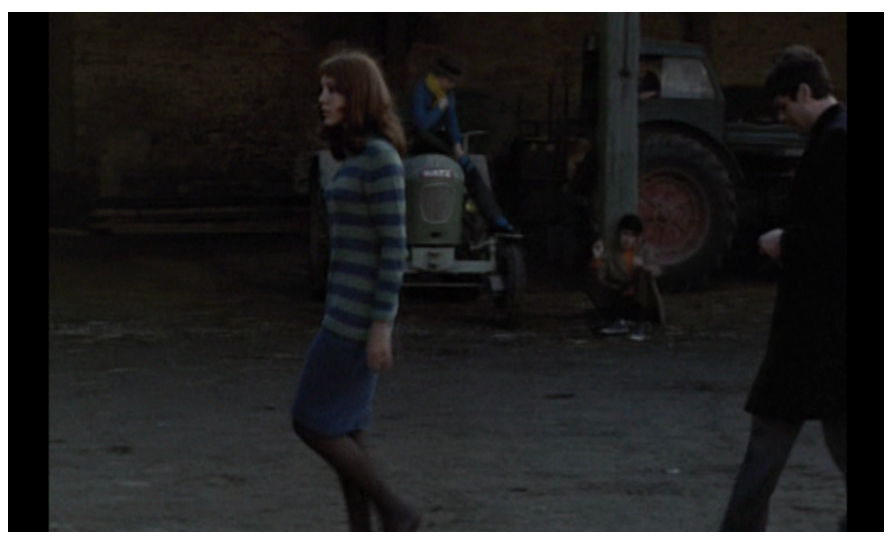

If we understand this young couple to provide a contrast with the workman, they also provide a foil for the subjects of the third visual structure, the protagonists Roland and Corinne. They are discovered by the camera 20 seconds into its first panorama, he standing yawning (same yawn each of the three times the camera finds him), she sitting, equally bored, so much so that early in the third panorama we notice her in the background, sitting at the feet of another man and holding his hand. She rejoins Roland a little over 
a minute later, entering the frame from the right, and the camera pauses on the two of them for half a minute before again picking up the workman and following him back to the piano and the end of the panorama. Between the younger and older set of couples, there is reinforced the narrative of bourgeois life: what takes place is the bourgeoisie enjoying its weekend.

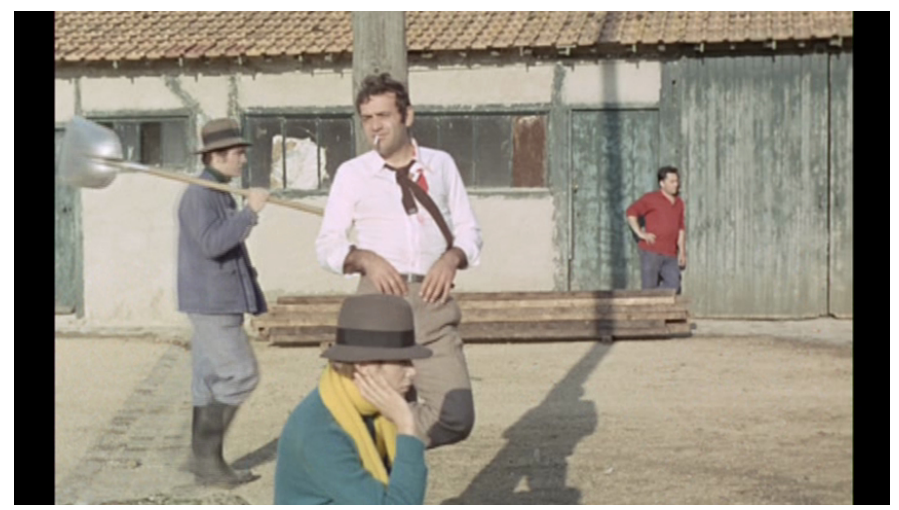

The point at which the final pan leaves Roland and Corinne to resume its clockwise sweep coincides with both the re-entry into the frame of the workman with his shovel, and the resumption of the piano recital. At the precise moment when we see both the protagonist couple and the workman, and also hear the sonata taken up again, we cannot say which narrative structure is driving the film: our interest in the protagonists, the movement of the workman, or the flow of the music. Music has therefore been invested with a narrative content (and classical music, of course, follows its own classical narrative structures) that to some degree competes with the major diegetic and thematic forces of the film. More importantly, it has come to inhabit the image. For neither can we say with certainty whether it is one or the other narrative structure, or one or the other set of movement-images (all of which inhabit the same camera shot), or something like a force of music that is at that point driving the film, indeed constituting it. It is not just that we have seen music being played; rather we "see" what we hear, to the extent that it is imbricated in, intersects or coincides--at least at the moment in question--with the structures of coherence functioning on the image track. At the 57'18" mark, where we encounter this coincidence or intersection between, on the one hand, the workman and the music that we have been following from beginning to end of this sequence, and, on the other hand, the couple we have been watching since the beginning of the film, the music can be understood to be seen even in the absence of a visual representation of piano and pianist.

Music here-and conversely, I would argue, the image-is therefore notable for a type of becoming-modernism different from its fragmentation in many, if not most, other films by Godard. Douglas Morrey has pointed 
out that these three panoramas provide a counterpoint to Week-end's famous tracking shot of the traffic jam, roadwreck carnage, the former's circularity contrasting with the latter's linearity. ${ }^{13}$ Both are of similar length (a little more or less than $7 \frac{1}{2}$ minutes), and both provide a sustained continuity of non-montage film time (in the case of the panoramas it is a single shot, in the case of the tracking shot an as-if-single $\left.\operatorname{shot}^{14}\right)$. Similarly, the relative integrity of the musical interlude contrasts with the cacophonous mayhem of much of the rest of Week-end's soundtrack, in particular two other onscreen "performances," the ubiquitous hornblasts of its first half, and the drumbeats that are constantly in the background of the Seine et Oise Liberation Front cell scenes. The Action musicale of Week-end thus constitutes a specific relationality of image and sound tracks, and among image, dialogue, ambient sounds, and music.

However, in the repeated comprehensive panning of Week-end's Action musicale, the spectator also sees the machinery of cinema; one cannot not be struck - experiencing the effects of a certain spatial disorientation - by the fact of seeing the camera turn through $360^{\circ}$. For, if the capacity to record movement provides a certain (tautological) definition of the moving picture, the cinema we are now acquainted with, and expect, derives rather from effects of montage combined with effects of a camera that records movement: that is what, for Deleuze, gives the movement-image. The Lumière Brothers in effect already produced that possibility, without knowing it, by stopping their static camera, acknowledging that if film had the capacity to reproduce the life of the living, it could not or would not preserve that life as flow. (However much they extend that possibility, Andy Warhol's Sleep and Empire, and ultimately Michael Snow's Wavelength, remain within its structural limits.) And as soon as Méliès filmed different scenes with a repositioned camera, film was well on the way to becoming an edited fiction. It would not be long before the basic constituent elements of a camera that stops and starts, dollies and pans, tilts and zooms, or is hoisted on a crane, were in play. Godard's recourse, in Week-end, and in the context of cinema (his in particular, but also cinema in general--whether it rely on Eisensteinian montage or continuity editing), to exaggerated tracking and panoramic shots, necessarily returns us to a type of naïve cinematic apparatus. From that point of view, beyond the visual, sonic, and narrative structures I just outlined, the panoramic musical scene enacts a certain technological constitution of cinema, and, I would argue, posits that as a "becoming-music." Within the limits of the sequence itself, such a becomingmusic remains actual, and territorialized, at least as long as the music is performed on-screen, within the diegetic structures. Paradoxically, for being perceived, its escapes the virtual reality that it will achieve in later films. But the possibility is, as it were, here put in place, on stage and into play: one sees the specific relationality of image, sound and camera movement, and one hears the music not just issuing from a piano being played on-screen, 
but as music being made within that complex and specific cinematic relationality.

There is, however, another performance, what could be called another "sound performance" in Week-end. I refer to its second sequence, four minutes into the film, Corinne's recital (the first word of the scene is her interlocutor's command "Recommence," suggesting some sort of repeat performance) of the facts of a tryst involving a male lover and his wife. A minute and a half into the 9 minute sequence we are given the intertitle "ANAL-YSE," but however much the male interlocutor conduct himself like an analyst, we know him to be the man we were introduced to in the previous sequence as Corinne's current lover, Paul. Besides, if this is an analytic séance, it is heavily erotically overdetermined, as she is sitting on the table at which he is seated smoking, in her underwear.

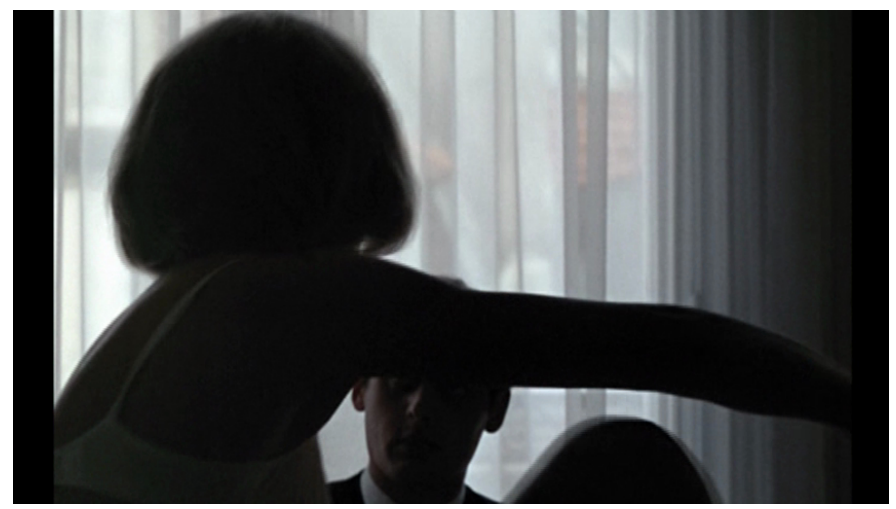

The restricted camera movements might allow one to interpret this sequence as even more elemental cinema than the tracking shot of the traffic jam and the repeated panoramas of the Mozart recital, except that we have seen in film after film by Godard reworkings of the traditional shooting of a conversation: most clearly, there is no use of the shot/countershot convention.

Corinne's account of her threesome might be understood to "track" the long flux, obstructed or unimpeded, of voyeuristic desire, for that is what the male participant stages; or we might imagine her recital to produce some sort of virtual pan into the libidinal space of, first Paul, then beyond the $180^{\circ}$ of the screen, toward the spectator. Like the Mozart recital, this sequence is also filmed as a single shot, with the camera remaining static except for limited zooming and panning. Once Paul has asked or told her to begin her narrative, it is Corinne who mostly occupies or dominates the frame, often in close-up, dimly lit and in relative contre-jour, so that the colors of the film are muted almost to monochrome. 


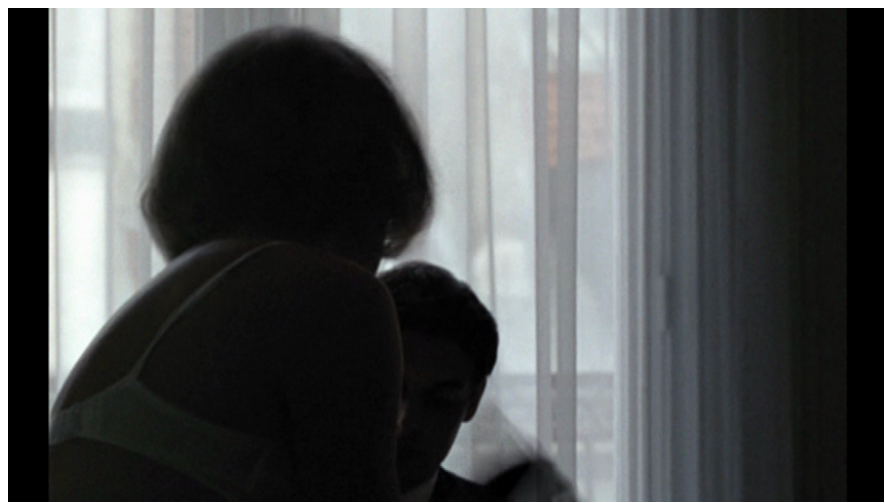

She is in three-quarters profile as she recounts her tale, sparing no detailcunnilingus, masturbation, and substantial elements of anal eroticism and $a$ tergo sex, as suggested by the intertitle. After $7 \frac{1}{2}$ minutes, she disappears in search of cigarettes, and returns to sit in the center of the frame in much more oblique right profile. For the remainder of the sequence we see only the back of her head obscuring Paul's face all but completely. What she now retells, still recounting the prompting of the man who is directing the scene ("A la cuisine les minettes, à la cuisine"), becomes, progressively more recognizably, a re-enactment of the milk and eggs scenes from Bataille's Story of the Eye. ${ }^{15}$

The soundtrack to this sequence also seems to be traditionally conceived, reduced to a dominance of dialogue (or monologue), and accompanying music. But just as the image track frustrates the conventions of the filmed dialogue, being practically devoid of reaction shots, the main speaker either turning her head away from her interlocutor, or offering the spectator only the back of her head and shoulders, so dialogue and music function in competition one with the other, such that were it not for the English subtitles one would have only the suggestion of much of the explicit sexual material. For Corinne's muffled voice is consistently drowned out by the often discordant and strident music when she is explaining details of the more perverse acts. Once again there are many other examples of such indistinct, or even silent speech in Godard's films, which again leads one to place the sequence in the classic category with respect to his repertoire. ${ }^{16}$ If I am insisting on comparing and juxtaposing it with the Mozart recital, it is for reason of its continuous camera and relative calm-it has the tone of an interlude, and is immediately followed by the altercation with the neighbors and then the traffic jam-as well as the way in which the music points outside the image. What it "points to" most explicitly in this case is the perverse sexual activity that is being described. It would be impossible to determine whether the scene that is recounted in Mireille Darc's soft melancholic monotone ${ }^{17}$ could in fact be represented more erotically in 
visual terms; that is, after all, the whole challenge, and impasse, of so-called sexually graphic cinema. But in one obvious sense what occurs is that certain details get represented instead in musical terms. By intervening to replace the dialogue at certain, sexually explicit moments--apart from giving Godard an alibi in a pre-sexual-revolution societal, and cinematic ambience-the music becomes a type of perceptual sign of the sex that is being unspoken, an "image" of the perversions that are being portrayed, at least structurally comparable to the classical cut or pan to a flaming fire at the point of consummation of the sex act.

However, Godard is not that prosaically metaphorical, even if one could counter that the discordant music is appropriate to the sex we are hearing about. The music less replaces the dialogue to figure or signify sexual acts than it sounds in a generalized space of excess with respect to the image. Corinne's distracted and detached recounting creates a strange disjunction between the scene's presence as dialogue, and its being positioned "off." It is thus already at least doubly absent, off screen and in the past, as well as detached from Corinne's experience of it. Indeed, in response to Paul's question at the end, "is it true or a nightmare?" she replies that she doesn't know, which adds a further dimension of "irreality." But if Corinne's detachment plays into the complex erotic system of Paul's desire ("Come here and excite $\mathrm{me}^{\prime}$ is his request or command as the sequence ends), of the voice, of voyeurism, and of a generalized eroticoexoticism that, of course, functions also for the spectator, if for those reasons the scene necessarily inscribes structures of distancing and plays on the unattainable object, I maintain that the music ensures that that is not the only way that the, or an outside is identified. Its effect, at those points where -again in a way that is comparable to the 57' $18^{\prime \prime}$ mark near the end of the musical panorama - it coincides with or produces an indistinctness of the voice, is precisely that of indistinction, of a signifying imprecision or excess. And at that "level" we can understand a specific form of the intersection or coincidence just referred to, represented by the name of Bataille. For his text is "heard" only in a muffled or muted way also, through the indistinctness of Corinne's voice and the discordance of the music, as well as by means of the somewhat oblique and unidentified reference to it (unlike, as we shall see, in Éloge de l'amour). Those familiar with Bataille's novels may recognize the reference in play here, but the spectator in general necessarily has imposed upon them the disturbing effect of a polymorphous perversity, a contagion such as Bataille recounts in The Story of the Eye, echoing pell-mell through "the void that yawned within us by means of our entertainments with the eggs." ${ }^{18}$ In the novel, that contagion or exceeding of the limits is indistinctly a multiplication of examples from the erotic repertory, and an overflowing of metonymic and metaphoric signifying processesculminating in a scene of cruelty the combines much of what is to come in Week-end, and more-adding up, especially for those who know Bataille, to an affirmation of sovereign desire, where the individual becomes less a 
subject than a desiring flux or machine. Of course no music, in the pure or simple sense, however complex it might be, can figure that, and, as I have argued, figuration or signification is no longer what is in play. Rather, music playing off and across voice and image at least points in the direction where cinema begins to think otherwise.

Éloge de l'amour explicitly cites Bataille, in at least three forms, recited and reworked through the complex chronology and characterology of the film. In the longest reference, about a third of the way through the film, a quotation from "L'Amour d'un être mortel" is recited and discussed in the context of Bataille's other main erotic novel, Blue of Noon, during an audition for the vague creative project-formerly a cantata, now perhaps opera, archive, film, sociological study-being developed by Edgar, the film's protagonist. It is something Edgar has heard two years ago, the text of which he has now stumbled across at a bouquiniste's stall. It deals with the opposition between the competing sovereign desires of the State and of love:

You say love, but nothing could be further from the image of the loved one than that of the State, whose reason is opposed to the sovereign value of love. The State in no way possesses, or it has lost, the power to embrace before us the totality of the world, that totality of the universe which is given at once outside, in the loved one as object, and inside, in the lover as subject. ${ }^{19}$

In an earlier reference ( $18^{\text {th }}$ minute), Edgar recalls the woman he wants to play in his "film," as offering "a real discourse, about the State, and the impossibility for the State to fall in love." Then, towards the end of the film, which takes place two years previously, Berthe, the woman in question, gives what is in fact the "original" version of the quote, a shortened paraphrase of it: "You say the State, but nothing could be further from the image of the loved one than that of the State, whose sovereign reason is opposed to that of love."

In purely analogical terms, given what I have already developed, one could understand the State/love opposition to be that between a certain order or regime of narrative cinema dominated by the image, and "music"; not just the opposition between image and sound, but between a present, perceived, sensory-motor cinema, and a potential or virtual musical "image." In Bataille's terms, the first would be "acquired" as part of a restricted economy, the second "consumed" in an excessive general economy. Blue of Noon, written in 1935 , is the story of a first person narrator who, towards the end of the novel, makes a more or less conscious choice in favor of erotico-morbid consumption over participation in the Catalan 
uprising in Barcelona. The revolutionary aspiration that the protagonist rejects, is incarnated, in the novel, by the character Lazare, understood to be modeled on Simone Weil, the subject of Edgar's cantata project and a constant reference in Éloge. Edgar's disillusion regarding the cantata, and his pursuit of Berthe, may be interpreted as an increasing sympathy for Bataille's insistence on a complex relation between revolutionary and amorous excess. In referring to Bataille's novel in the audition sequence, for the benefit of the actor who has never heard of him, Edgar regrets that when it comes to the Spanish Civil War, Malraux's Hope, a classic novel of engagement, is consistently cited whereas Blue of Noon is ignored. ${ }^{20}$

What we might call the immediate syntax of reference to Bataille in Éloge de l'amour, that which takes the three instances as they appear filmically, without considering their more complex diegetic chronology, provides a cinematic staging of the opposition I am describing. For if we compare the three instances, we hear first an imprecise mention (evocation of someone "not very attractive," but who dared to say things), second a contrived recital (the audition), and finally the "original" instance (Berthe's voice). The audition is filmed as is, with an actor given the script and asked to read it; there is no obvious rupture of cinematic continuity. The other two, as it were framing instances, are less transparent.

The first instance begins with a shot of three characters-a couple, and a solitary man (played by Godard) - sitting back to back on two benches on a Paris street at night.

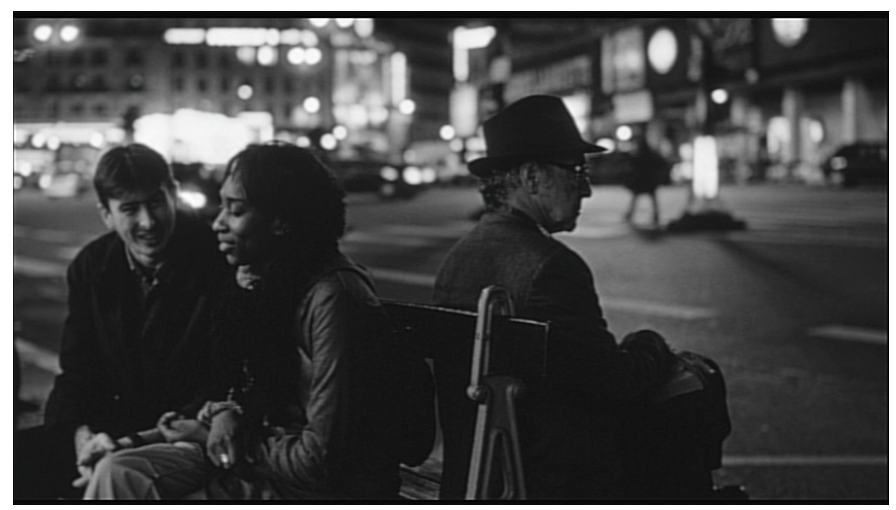

The ambient sounds of the traffic and the voices of the couple, whom we see laughing and speaking, are just audible (that ambient sound continues throughout and into the following sequence). 


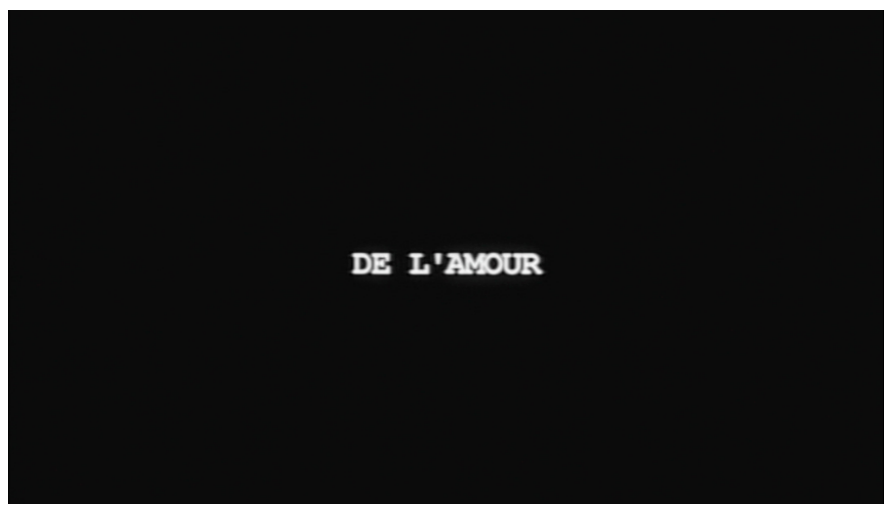

The next shot involves a cut to a black screen (between Edgar's voice-over words "State" and "impossibility"), followed by the appearance of the intertitles de l'amour ("of love") and de quelque chose ("of something"), part of the expanded version of the film's title, fragments of which have been projected a number of times since the beginning.

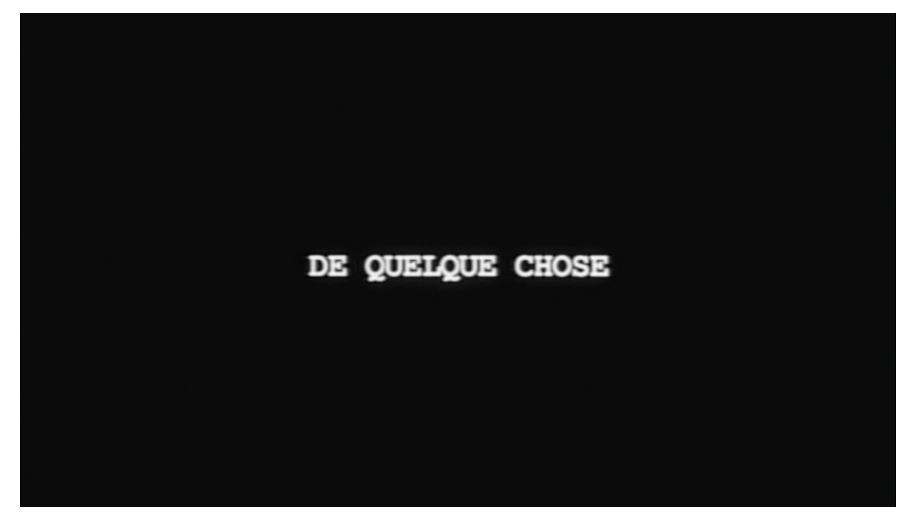

In the later instance, Berthe's voice-over begins as documentary footage of three men looking at skeletons from the Holocaust stops with a freeze frame on one of the men, who turns and walks toward the camera. That still image cuts to a black screen (between the words "State" and "sovereign reason"), then again to a gramophone turntable with an LP record turning (the soundtrack will cut from "Bataille" to Celan reading his "Todesfuge"). During the voice-over one hears ambient footsteps, presumably diegetic (stiletto heels of the African-American assistant). 


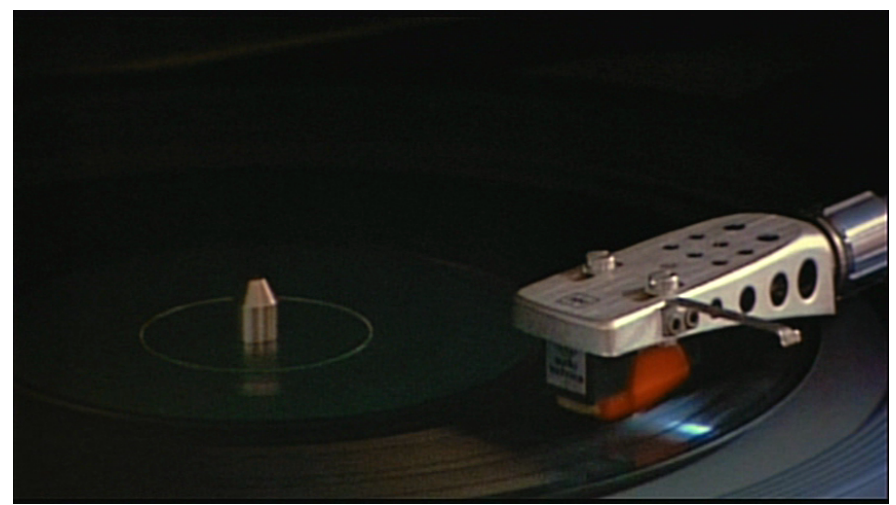

There is no music in any of the three sequences. ${ }^{21}$

The audition, in my terms, is cinema, ordinary cinema. It may be something of a mise en scène of that ordinary cinema, even that ordinariness of cinema, which Edgar refuses, saying at the end "it won't work," such that we can hear his frustration being expressed in terms not just of the shortcomings of the surprised actor, but also of his whole project. The other two citations or evocations of Bataille exceed the economy of ordinary cinema, in the first place by means of the montage of, in each case, three contrasting shots: black and white street scene, black screen, intertitle; black and white freeze frame, black screen, gramophone. In the second place, however, the blank, black screen that occurs as the central shot of both montages exceeds the economy of ordinary cinema by presenting a form of cinema's negation: an anti-image, the image of a lack of image. Now, if, on the one hand, we were to impose a structural organization, derived from the three-shot montage, upon the three instances of reference to or quotation from Bataille, reading them as another discontinuous montage connected by the dialogue track repetitions, we might compare the middle instance (the audition) with the middle shot of the other two instances, namely the black screen. That is: if there are three instances, and each of the three-shot, outside framing instances has a black image at its center, then the central instance can be read en abyme as black, in spite of its obvious visibility. That would make the ordinary cinema of the audition a non-image, equivalent to seeing only darkness, there being nothing much to see. Edgar's disappointment reinforces that reading: it's not going to work, the audition isn't working, my film project won't work, cinema doesn't work, one may as well be watching a black screen.

On the other hand, consonant with what I first suggested about the "music" of a potential or virtual image, we might be tempted to read the cut to black with voice-over relating to Bataille as more literally that, a cut "against" the image in the sense of a cut out of the image, into what can no longer be seen; not just into what can be heard instead, but rather into or 
toward an outside of cinema where what is seen is seen as (though) heard. That would represent some sort of indomitable sovereignty of the "musical" image analogous to an image of the loved one in opposition to an image of the State; or at least a relation of cinematic elements whereby virtual and actual images correspond to image of loved one and image of State (and one cannot help but think that what resonated for Godard in the Bataille quote was precisely the word "image"). It would be important to understand that move toward an outside of cinema, into what I am calling the "musicimage," as something very different from an ineffable, musical or mystical cinema such as is presumed by various commentators who discuss Godard's work, and his use of music, from 1980 on. Laurent Jullier, for example, argues "that Histoire(s) is not so much a work of history as one of sensory experience, an attempt to reach the ineffable, mainly through the soundtrack"; James Williams considers that if Godard is silent about music's "increasingly concrete and plastic role in his work" it is because "music is a mystery for him . . . . It is ineffable; it simply is." ${ }^{22}$ On the contrary, I would have that musical outside of cinema understood precisely as history ([de] l'histoire), in contrast to just a story (une histoire), according to the delineation that is consistently made explicit in Éloge de l'amour. That is somewhat how Douglas Morrey would have us understand the "tender and unconventional love story" of the film, in the context of a history that has to be worked at, inasmuch as "the complex montage of Godard's film, which requires the spectator to work to reconstruct a narrative, seeks to demonstrate this sense of history as an active process." ${ }^{23}$ If Edgar insists on not representing a story to the extent of having his project fail, it is not because that story existed, but in a past that cannot now be retrieved; it is rather because he wants to represent history, that story as history. And if the difficulty of that story as history derives from its being understood as love, it would be not because love is in opposition to history (some opaque private story versus history as something public and transparent), but precisely because it deals with the very political intransigence of a love that declares itself to be sovereign. No simple image, no simple film, no simple cinema can represent that; it won't work. If it can be figured, it is only in a relation between represented and non-representable, which is where the film leads by means of Bataille, into a black screen that does not reduce simply to no image, but rather tends toward a music-image. As long as the image is relating to what is outside it, a "crystal-image" in Deleuze's terms, "the indivisible unity of an actual image and 'its' virtual image," ${ }^{24}$ I would maintain that cinema is precisely prevented from falling, or leaping, via "music" into the ineffable.

A number of elements reinforce what I am arguing. First, in almost literal terms, the black screen of the first three-shot framing instance of Bataille, gives way to the words de l'amour, inscribing upon the blackness, however temporarily, a signification. (Some) love is to be "seen" here, set against the darkness. Something of the image of sovereign love, or something of the sovereign image of love, we read, is in, through, or on the 
other side of this darkness. But that signification is quickly qualified by de quelque chose: love is not something abstract or ineffable, it comes to be historicized as the particular instance of love of something; the abstraction de l'amour comes down to some material level, the level of some thing. It has not been sufficiently emphasized in discussion of Éloge de l'amour that what is being praised in the title does not remain, for longer than forty seconds into the film--and no longer than a momentary shot of blank pages--simply love. Éloge . . de l'amour . . de l'amour . . de quelque chose is how the title is read, and the words de l'amour . . . de quelque chose are repeated a minute later, and at various moments during the film. When the art dealers are speaking of Edgar's project its title is said to be "something of/about love, "praise' I think" (quelque chose de l'amour, "éloge" je crois). The words quelque chose thus repeat both an imprecision, and a qualifying precision that makes the film no more specifically about love tout court, or Edgar's love for Berthe, than it might be, for example, about a camera's love for Paris, or love of cinema; and no more, as I am suggesting, about love through history (Tristan and Isolde, the resistance couple), than about love as history.

The second reason to read the musical outside of cinema as history functions through the second framing montage, where the black screen is preceded by a still that evokes the Holocaust (spectators/museum visitors before a heap of skeletons), and followed by a spinning LP record that will come to be heard as Celan reading "Todesfuge." We move from a documentary representation of the Holocaust, through black screen, to a poetic evocation of it, or at least to the proleptic announcement, on the image track (turning LP), of what will become a poem of the Holocaust. The cut to black is, of course, a cut to a type of contemplation that supersedes and exceeds what a documentary, however well-intentioned and historical, can tell us of the Holocaust; recognition of the impossibility of representing it, the impossibility of poetry after it. But, as I read the syntax of the images here, the black screen that appears immediately after we hear the words "th[e image] of the State," goes further than the simple recognition of failure or the impossibility, for example on the part of cinema, of representing the Holocaust, which we know to be the structuring impulse of Histoire(s) $d u$ cinéma and, by extension, Éloge de l'amour. In the first place we are now "looking at" a State whose murderous totalitarian excess perversely rejoins, in Bataille's terms, certain aspects of erotic excess, as is suggested by the end of Blue of Noon (which is not to say that Bataille thereby either encouraged or celebrated fascism). The Nazi "rising tide of murder" is clearly a proleptic fact of Bataille's novel, and the culmination of the narrator's sexual relations with Dirty-in particular the scene in the cemetery in Trier-forms a stark contrast, and a form of resistance (as well, perhaps, as a morbid attraction to) to the increasingly militarized social and political background.$^{25}$ In the black screen said to be an image of the State we might be looking at such a history, one that morbidly or obscenely comes back to meet "love" on the other side of it. If there is music in or as that history, it would necessarily be a 
particularly tortured music far from the contemplative lyrical form it adopts in most of Godard's usages of it, on the other side of such lyricism. That, of course, is something music can be (as in the strident tones of Week-end). Yet, once the image cuts again, we take a further step beyond: Godard suggests by means of the LP, and then with Celan, that there remains, miraculously even, miraculously and torturously, the potential for more music, another lyric.

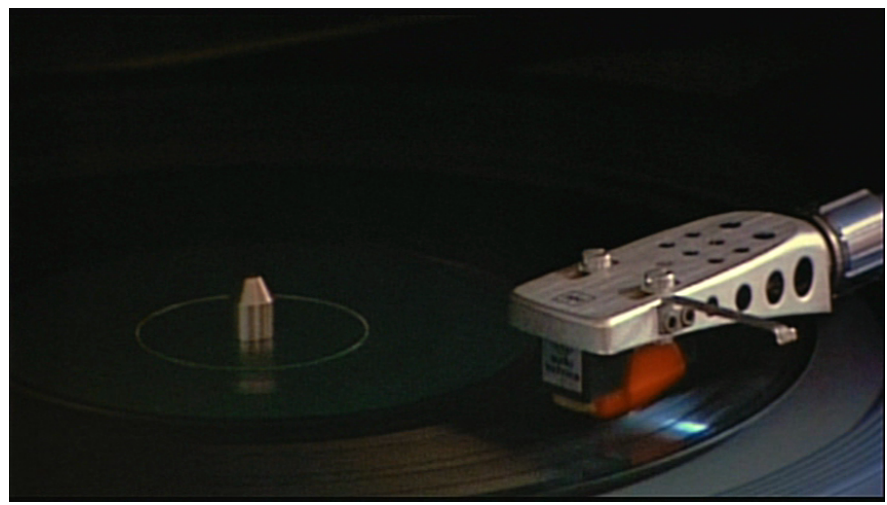

The shallow focus of the close-up on the record means that it fades out of focus and into black about halfway up the image, so that the upper half of the screen is still as blankly black as the previous image. We can see this image less as one that comes to be attached by horizontal montage to the previous one, than one that is stuck to it, or half torn away from it. We see a half-image of previously unseen music-I think it is fair to say that a spinning LP signifies in the first instance music - and a half-image of music leftover from the black screen. According to this interpretation, the Bataille voice-over conjoined with the cut to black takes us out the other side of darkness into an image of music, and further still into the music of history recited by Celan.

Lastly, we can see music as history by means of the very fact of montage, cinema's rhythm of dialectical progression. Godard has used the interrupted time of montage, as exemplified in the syncopated effects we have been examining here, to greater advantage than any other filmmaker. Montage thus becomes, finally, as the film of the same title explains, our music. In Notre musique, notre musique is apposed, by Godard in his lecture, to the "principle of cinema," which in his formulation consists in "going toward the light and directing it on our night...our music":

Shot and reverse shot. Imaginary, certainty; real, uncertainty. The principle of cinema: go to the light and direct it on our night ... our music (Champ et contrechamp: imaginaire, certitude; réel, incertitude. Le 
principe du cinéma: aller à la lumière et la diriger sur notre nuit . . . notre musique.).

In the interrupted syntax of that dictum (whose precise punctuation is difficult to determine), music is in fact apposed either to the principle of cinema, or to our night. But as is clear from the immediate context of the statement, and in the syntax or narrative of Godard's discussion up to that point, we can understand the principle of cinema to function by means of montage, the appositions of shot and reverse shot, by which there is either a simple repetition of sameness that masquerades as difference or as opposition (which is what happens in dominant conventional film - the example shown is from Howard Hawks), or a difference that emerges from an apparent sameness, for example two news photographs showing opposing sides of a political situation (Israeli/Palestinian, or as in the disturbing categorization of resistant or compliant concentration camp victims, Jew $/$ Muslim $^{26}$ ). In one version of the productive application of that principle, one progresses through the dialectic to achieve a truth about reality (light shed on our night); in another version, one achieves something closer to the sacred, in various forms (the iconic value of the Virgin of Cambray, or the martyrdom that the film's young protagonist seeks and seems to achieve). Both are, as it were, beyond vision, at least cinematic vision: the Virgin has "no movement, no depth, no illusion"; the prospect of martyrdom (whose cinematic pedigree comes from Dreyer's Passion of Joan of Arc) necessitates closing one's eyes, providing a representation to oneself ("imagining," as the subtitle has it), rather than looking.

Much of Godard's work of the period of these two films, and in particular the Histoire(s) du cinema project, involves intense investigation of, and experimentation with, that principle. That would already be another cinema, a whole other combination and juxtaposition of images, and of image and sound, an extraordinarily rich and productive reworking of the story and history of cinema that has been given us, especially in its relation to History as measured by a failure to represent, or even prevent Auschwitz. It would already be a transformation of the principle of cinema as it has been enacted in countless films; already an unheard music in and of cinema.

Yet if we attend to the other side of the juxtaposition of our night and our music that Godard produces, precisely our music as our night rather than the light cinema seeks to shine on that night, it sounds different again. For in the images that accompany the explication of the principle of cinema "go to the light and direct it on our night ... our music" - Godard again has recourse to the darkness of a blank screen. At the point at which the words "notre musique" are uttered, the image is blank not just in the sense of dark, but rather emptied of the visible. 


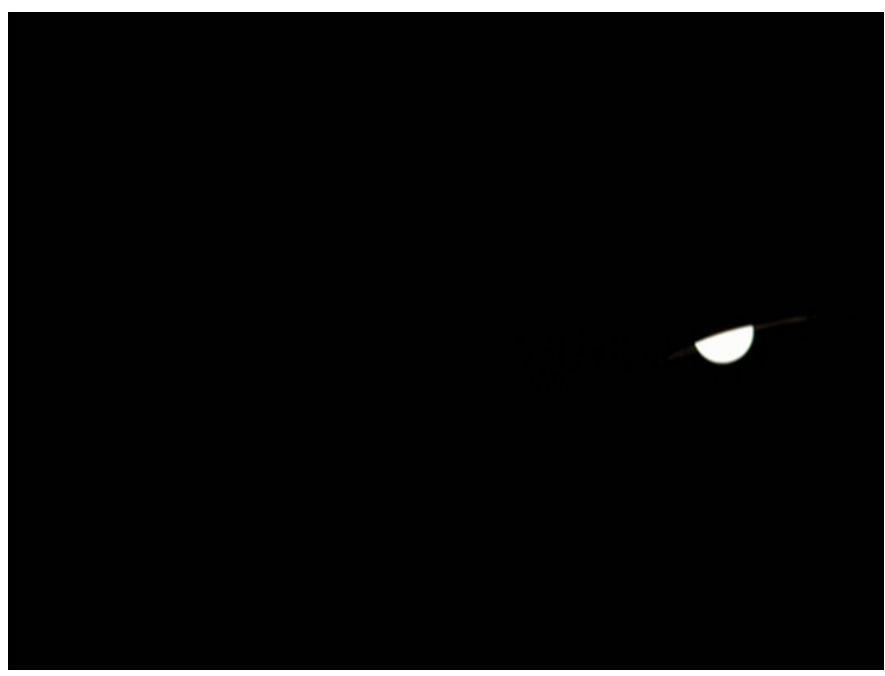

A lightbulb has been swinging back and forth across the screen while Godard emphasizes the effects of the shot/reverse shot opposition; mostly, it has swung just to the left and right edges of the frame--the bulb being dissected by those edges--but now it swings out of the field of vision.

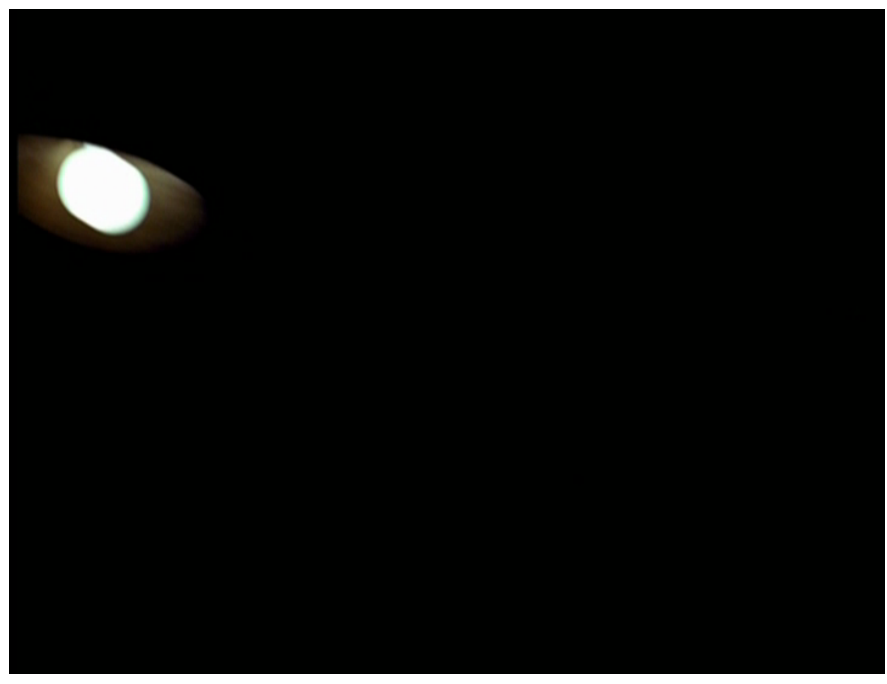

But it in fact swings more radically outside the range of its pendulum movement, for as it moves, left to right, to the edge of the shot, there is a cut to darkness while the words "notre musique" are uttered; then the light reappears from the left. We have a classic case of the bad splice that Godard has been provoking us with since the opening minutes of $A$ bout de souffle. 
But more than that: the movement of cinema has ceded the image to darkness and to the rupture of montage. Without that, Godard would insist, the image cannot tell any truth, it cannot shine any light, it cannot measure up to history. But because of that, Godard would seem to suggest, from at least as far back as Week-end, as I have tried to argue, the dialectic of juxtaposed images is subjected to its own outside potential, which is an excess beyond any simple opposition. If our music is heard in the film of that name, beyond the ECM extracts that form a rich counterpoint to the film, beyond montage as productive of a photocentric revelation, it is because it is understood also as the montage of our night, something seen beyond vision, something seen heard on the other side of the image.

In this way Godard might be said to have achieved a visual montage of music, ceding the image to a type of sovereignty that exceeds it, but by means of its most intimate or immanent technological possibility. "In film," he has said, "there's rhythm, it's more like music, that's how I came to use black for rhythm" ${ }^{27}$ : the rhythm, therefore, of a varied syntax of shots, whether exaggerated panning and static takes, complicated montage combinations, or the adventures in digital color of these later films; as well as the rhythm, as we have seen, that is punctuated by black. But it is not only in the sense of temporal measure and syncopation that music comes to be incorporated into the visual track. In staging cinema's discontinuity-the inanimation of montage that makes it tick-as a means to have it sensed otherwise, Godard creates for it a different type of flow. As a result there resounds in his films the tonality and beating of another form of cinematic life.

1 I attempted briefly to outline this logic, with particular reference to Sauve qui peut and Prénom Carmen in "Representing Silence (in Godard)," in Bruce Merry (ed.), Essays in Honour of Keith Val Sinclair. (Townsville: James Cook University Press, 1991), 180-92.

${ }^{2}$ For the first two of these terms, see my Prosthesis (Stanford: Stanford University Press, 1995) and Dorsality (Minneapolis: University of Minnesota Press, 2008). For autokinetic ipseity, see Derrida, for example The Animal That Therefore I Am, trans. David Wills. (New York: Fordham University Press, 2008), 65, 94-95, 125-26.

${ }^{3}$ Cited in Jean-Luc Douin, Jean-Luc Godard. (Paris: Rivages, 1994), 99-100, my translation and italics. The end of Sauve qui peut is inscribed within the same logic: "when Scarlett O'Hara is kissing Rhett Butler and you hear the hundred violins of the Boston Symphony Orchestra, or when the Russian Army crosses and we hear the hundred violins of the Chicago Orchestra . . . we want to see the music." "A New Direction for the New Wave's Jean-Luc Godard (interview with Annette Insdorf)," in David Sterritt (ed.), Jean-Luc Godard: Interviews. 
(Jackson: University of Mississippi Press, 1998), 89. See also, for example, Jacques Aumont: "Godard is interested neither in the 'grand form' nor the musical phrase for itself, but in the musical idea" ("Lumière de la musique," Cahiers du cinéma 437 [Supplément spécial Godard] [1990], 46-48).

${ }^{4}$ Adrian Martin, "Recital: Three Lyrical Interludes in Godard," in Michael Temple, James S. Williams and Michael Witt (eds.), For Ever Godard. (London: Black Dog Publishing, 2007), 255.

${ }^{5}$ Gilles Deleuze and Félix Guattari, What is Philosophy, trans. Hugh Tomlinson and Graham Burchell. (New York: Columbia University Press, 1994), 2.

${ }^{6}$ Claire Colebrook, Deleuze: A Guide for the Perplexed. (London: Continuum, 2006), 4. Colebrook's book, in spite of its somewhat minimal referencing, and a title that suggests a simplification or vulgarization, is a serious engagement with Deleuze's thinking, especially as oriented around the questions that concern me here.

${ }^{7}$ Ibid., 5.

${ }^{8}$ D.N. Rodowick, Gilles Deleuze's Time Machine. (Durham and London: Duke University Press, 1997), 139.

9 Gilles Deleuze, Cinema 2: the Time-Image, trans. Hugh Tomlinson and Robert Galeta. (Minneapolis: University of Minnesota Press, 1989), 141.

${ }^{10}$ Rodowick, Time Machine, 201

11 Deleuze, Cinema 2, 81. Space limitations require that the present article stop short of examining, in a kind of obverse reasoning to what is presented here, a number of questions, some but not all of which arise out of Derrida's discussion already referred to: the autonomy or sovereignty of what I call, by the end, the image of music, in terms of technological, as compared to animal auto-motricity; whether a concept of power or potential such as Deleuze develops can avoid the problem of sovereign ipseity in Derrida's terms; the implications of a sound-image or music-image for a life of cinema presumed to derive from the movement-image; the relation of the music-image to Godard's radical use of digital color; and, perhaps most importantly, the possibility of defining relationality in general as technological before it becomes an image. I hope to develop those questions in a later discussion.

12 A flawless "spatio-temporal integrality," where on-screen time equals real time, as in a theatrical scene (Christian Metz, Film Language: A Semiotics of the Cinema, trans. Michael Taylor. [New York: Oxford University Press, 1990], 129)

${ }^{13}$ Douglas Morrey, Jean-Luc Godard. (Manchester: Manchester University Press, 2005), 77.

${ }^{14}$ Raoul Coutard comments on the practical problems of producing the famous traffic jam shot in Colin MacCabe's “Interview with Raoul Coutard” on the DVD of Week-end (New Yorker Films, 2005).

${ }^{15}$ George Bataille, Story of the Eye, trans. Joachim Neugroschel. San Francisco: City Lights, 1987, 4-5, 10-11, 5-40. A la cuisine les minettes literally means “(Let's go) to the kitchen, babes," but la cuisine also refers to where things (sexual and otherwise) get cooked or heated up.

${ }^{16}$ See Godard's explanation concerning having only two hands, hence being able to use only two tracks of sound at any given time: "all my films since Sauve qui peut have only two mixing 
tracks. You know, in the cinema, when it comes to making up the final sound track, there are always many original tapes-the sound of a car arriving at the beach, for example, the voices of the actors getting out of it and saying 'I love you' or the opposite, the sound of the waves behind them, maybe a cock crowing in a nearby farm, and some music. That makes five tracks . . . and I have only two hands to manipulate them . . . if I had only one arm, maybe l'd have only a single sound track. All this business of having the various sounds marching up in front of you like soldiers is called mixing and I can only control it with the two hands I have" (Gideon Bachman, "The Carrots are Cooked: A Conversation with Jean-Luc Godard," in Sterritt [ed.], Jean-Luc Godard: Interviews, 134).

${ }^{17}$ In this respect she recalls Brigitte Bardot in Contempt, lying naked, playing with her hair in a similar way while speaking to her husband, and in both cases Godard has wrung from commercially popular actresses whom he didn't want, performances of considerable, and understated, emotional depth.

${ }^{18}$ Bataille, Story of the Eye, 40, translation modified.

${ }^{19}$ Cf. Georges Bataille, “L’Amour d'un être mortel," Oeuvres complètes VIII. (Paris: Gallimard, 1976). As Stuart and Michelle Kendall point out, the text is reworked in The Accursed Share, vol. II, trans. Robert Hurley. (New York: Zone Books, 1991), 157-71 (cf. Georges Bataille, The Unfinished System of Nonknowledge, trans. Stuart and Michelle Kendall. (Minneapolis: University of Minnesota Press, 2001), 280n69). For further interesting discussion of Godard's use of the text, including in Histoire(s) du cinéma, see Douglas Morrey, "History of resistance/resistance of history: Godard's Éloge de l'amour (2001)," Studies in French Cinema 3, 2 (2003).

20 See Georges Bataille, Blue of Noon, trans. Harry Matthews. London: Marion Boyars, 1988. Regarding Weil as model for Lazare, and their intellectual debates in general, see Alexander Irwin, Saints of the Impossible: Bataille, Weil, and the Politics of the Sacred. (Minneapolis: University of Minnesota Press, 2002), 82-123. Irwin (82-86) discusses in detail the argument between Bataille and Weil over Malraux's Human Condition during their collaboration on the journal La Critique sociale, not long before Bataille began writing Blue of Noon.

${ }^{21}$ I am aware that a complex problematic arises concerning how to circumscribe the fragments from Éloge, and later Notre Musique, that I am privileging here. I am exploiting a certain limit determined by the explicit soundtrack reference to, and quotation from Bataille, while also profiting from a contextual overflow that occurs, especially on the image track (but also, as we shall see, on the soundtrack). Whereas the audition scene is self-contained as a sequence, the framing instances are more complicated: the first occurs within a larger conversation that takes place in a car; the beginning and end of the second are difficult to determine. I note simply that: i) given Godard's use of montage, the terms "fragment" or "sequence" are themselves problematic terms; and ii), the idea of a musical outside to the image that I am developing here presumes a more radical fracturing of the filmic surface, such that the cohering unity of any larger or smaller grouping of images remains both arbitrary and unstable.

${ }^{22}$ Laurent Jullier, “JLG/ECM,” in Temple, Williams and Witt (eds.), For Ever Godard, 274; James S. Williams, "Music, Love, and the Cinematic Event," in For Ever Godard, 292.

${ }^{23}$ Morrey, "History of resistance/resistance of history," 121, 123. Morrey does not clearly argue that it is in the unconventional love story that history comes to be found, preferring to see the latter's "recalcitrance" (124) analyzed in more conventional references-Nazism, the Shoah, and the Resistance; 1968; Kosovo. But he does establish a structural comparison in 
Éloge between history's recalcitrance and the elusiveness of that love story, "resolutely opposed to the formation of the couple which tends to organize the Hollywood romance" (126), and suggests that idea "could perhaps be articulated around" the Bataille text (128), while declining to pursue the structural comparison into the State/love contrast developed by Bataille.

${ }^{24}$ Deleuze, Cinema 2, 78. Interestingly, Deleuze's reference to Godard in this context is to Passion's process of production of "pictorial and musical tableaux vivants" (76).

${ }^{25}$ See Blue of Noon, 142-51.

${ }^{26}$ See Giorgio Agamben, Remnants of Auschwitz: the Witness and the Archive, trans. Daniel Heller-Roazen. (New York: Zone Books, 2002), 41-86. Cf. Godard: “No one but me has said that at one point in the extermination camps the Germans had decided to declare a Jew to be a Muslim" (Godard and Ishaghpour, Cinema, 105).

${ }^{27}$ Jean-Luc Godard and Youssef Ishaghpour, Cinema: the Archeology of Film and the Memory of a Century, trans. John Howe. (Oxford: Berg, 2005), 24. 